\title{
Activation of Human Eosinophils In Vitro by Respiratory Syncytial Virus ${ }^{1}$
}

\author{
JAN L. L. KIMPEN, ROBERTO GAROFALO, ${ }^{2}$ ROBERT C. WELLIVER, AND PEARAY L. OGRA ${ }^{2}$ \\ School of Medicine, State University of New York at Buffalo, Departments of Pediatrics and Microbiology, and \\ Division of Infectious Diseases, The Children's Hospital, Buffalo, New York 14222
}

\begin{abstract}
To determine the nature of the interaction between viruses and eosinophils, normodense eosinophils were separated from the blood of healthy volunteers and incubated in vitro with respiratory syncytial virus (RSV). After incubation for $2 \mathrm{~h}$ with the virus, $29.5 \pm 15.8 \%$ of the eosinophils demonstrated specific binding of the virus to the cell membrane, as detected by fluorescent staining with an anti-RSV MAb. Superoxide production and leukotriene $C_{4}$ release were measured as determinants of cell activation. Using a cytochrome $c$ reduction assay, superoxide could be detected in the supernatant $30 \mathrm{~min}$ after exposure to RSV. Maximal release was reached at $3 \mathrm{~h}$ postexposure $(5.88 \pm 2.19 \mathrm{nmol}$ cytochrome $c$ reduction/5 $\times 10^{5}$ cells). The virus-induced superoxide generation varied in magnitude among different subjects and ranged from 0.6 to $11.5 \mathrm{nmol}$ cytochrome $c$ reduction $/ 5 \times 10^{5}$ cells. RSV also appeared to prime eosinophils to the effects of other known cell activators, as demonstrated by an increase in superoxide production upon subsequent stimulation of RSV-primed cells with phorbol-12-myristate-13-acetate $(21.4 \pm 5.8$ versus $9.4 \pm 2.7 \mathrm{nmol}$ cytochrome $c$ reduction/ $5 \times 10^{5}$ cells for primed and unprimed cells, respectively) $(p<0.04)$. RSV did not directly induce leukotriene $\mathrm{C}_{4}$ release from the eosinophils but primed the cells to exhibit a more vigorous response on subsequent challenge with the calcium ionophore A23187 (9.16 \pm 1.04 versus $4.2 \pm 1.3$ ng leukotriene $\mathrm{C}_{4} / \mathbf{1} \times 10^{6}$ cells $)(p<0.005)$. These findings indicate that RSV can activate or prime eosinophils to release various inflammatory mediators. Such virus-induced effects on inflammatory cells may play a role in the pathogenesis of RSV bronchiolitis and may also be critical for the development of persistent airway hyperreactivity after viral infections. (Pediatr Res 32: 160-164, 1992)
\end{abstract}

\section{Abbreviations}

RSV, respiratory syncytial virus

PMA, phorbol-12-myristate-13-acetate

PAF, platelet activating factor

$\mathrm{LTC}_{4}$, leukotriene $\mathrm{C}_{4}$

HBSS, Hanks' balanced salt solution

SOD, superoxide dismutase

m.o.i., multiplicity of infection

Received September 27, 1991; accepted March 12, 1992

Correspondence: Dr. J. L. L. Kimpen, Department of Pediatrics, Academisch Ziekenhuis Groningen, 59 Oostersingel, 9700 RB Groningen, The Netherlands

Supported by National Institute of Allergy and Infectious Diseases, National Institutes of Health Grant No. AI 15939-11. Dr. Kimpen is the recipient of a NATO Research Fellowship.

'Presented in part at the meeting of the Society for Pediatric Research, Los Angeles, 1990 (abstr 932).

${ }^{2}$ Present address for Drs. Ogra and Garofalo: Department of Pediatrics, UTMB at Galveston, Child Health Center, Galveston, TX 77550-2776.
RSV is the leading cause of pneumonia and bronchiolitis during infancy (1). It has been speculated that RSV infection in infancy plays a role in the development of hyperreactive airway disease in later life (2). The pathogenesis of the inflammation of the airways during acute RSV infection and the mechanisms underlying the possible development of subsequent airway hyperreactivity are not completely understood.

Recent evidence suggests an important role for eosinophils in a variety of inflammatory states (3). Although the role of eosinophils in natural RSV infection is unclear, reports of field studies with a formalin-inactivated RSV vaccine carried out in the late 1960s suggest a role for eosinophils in disease due to RSV. Lymphocytes and eosinophils predominated in the airways on autopsy of two patients who died as a consequence of severe RSV bronchiolitis after vaccination (4), and children who had more severe bronchiolitis when subsequently infected with the natural virus demonstrated an increased blood eosinophilia compared to the controls (5). In addition, the release of $\mathrm{LTC}_{4}$ in the respiratory tract during RSV infection has been described $(6,7)$, and we recently showed higher levels of eosinophil cationic protein in nasopharyngeal secretions of children with natural RSV bronchiolitis in comparison with children affected only by RSV upper respiratory tract infection or non-RSV respiratory illness (8). The present study was therefore undertaken to examine in vitro the nature of interaction between RSV and eosinophils.

\section{MATERIALS AND METHODS}

Human volunteers. Peripheral blood $(120 \mathrm{~mL})$ was obtained in heparinized syringes from healthy adult volunteers who had a differential eosinophil count of $1-4 \%$. The subjects had no respiratory disease for at least $3 \mathrm{wk}$ and had not taken any medication for at least $3 \mathrm{~d}$ before sampling. Signed statements of informed consent were obtained. All subjects had serum antibodies to RSV as measured by ELISA (9).

Preparation of eosinophil suspensions. Percoll dilutions were prepared as described previously, with modifications (10). Briefly, a stock solution of Percoll was prepared by adding 1 part HBSS $10 \times$ to 9 parts Percoll. The osmolality of this solution was measured with a freezing-point osmometer (The Advanced Micro-Osmometer model 3MO; Advanced Instruments, Needham Heights, MA) and adjusted to $340 \pm 1 \mathrm{mosmol} / \mathrm{L}$. The density was measured with a glass 2-mL pyknometer (Ace Glass Incorporated, Vineland, NJ). From this stock solution (density 1.123 $\mathrm{g} / \mathrm{mL}$ ), five Percoll solutions with gradually increasing densities $(1.080,1.085,1.090,1.095$, and $1.100 \mathrm{~g} / \mathrm{mL})$ were prepared by adding calculated amounts of HBSS $1 \times$. All densities were verified by measurement with a pyknometer. Manipulations of the solutions were carried out under sterile conditions and the Percoll solutions were checked regularly for bacterial or fungal contamination by microscopic examination and culture.

Discontinuous Percoll gradients were prepared in $15-\mathrm{mL}$ conical plastic tubes (Falcon Plastics, Los Angeles, CA), using a 
peristaltic pump (Peristaltic Pump P1; Pharmacia Fine Chemicals, Uppsala, Sweden). Two and one half $\mathrm{mL}$ of $1.080 \mathrm{~g} / \mathrm{mL}$ Percoll were underlayered subsequently with $3 \mathrm{~mL}$ of $1.085 \mathrm{~g} /$ $\mathrm{mL}, 3 \mathrm{~mL}$ of $1.090 \mathrm{~g} / \mathrm{mL}, 2.5 \mathrm{~mL}$ of $1.095 \mathrm{~g} / \mathrm{mL}$ and $1.5 \mathrm{~mL}$ of $1.100 \mathrm{~g} / \mathrm{mL}$ Percoll.

Five parts blood were mixed with one part $4.5 \%$ dextran and left at room temperature for $45 \mathrm{~min}$ to sediment the red cells. Twenty-mL aliquots of the leukocyte rich supernatant were underlayered with $10 \mathrm{~mL}$ Ficoll-Hypaque $(1.076 \mathrm{~g} / \mathrm{mL})$ and centrifuged $(450 \times g, 20 \mathrm{~min}$ at room temperature). The cell pellet was collected and washed twice with HBSS $1 \times$ without calcium or magnesium and finally resuspended in HBSS $1 \times$ with $5 \%$ neonatal calf serum. A cell count was performed with an automated counter (Coulter counter S+IV; Coulter Corporation, Hialeah, FL), and the suspension adjusted to $20 \times 10^{6}$ cells $/ \mathrm{mL}$. Two $\mathrm{mL}$ of this cell suspension were layered on top of each Percoll gradient and centrifuged $(600 \times g, 20 \mathrm{~min}$ at room temperature).

Cells from the three lower interfaces $(1.100-1.095,1.095-$ 1.090 , and 1.090-1.085) were collected and washed twice in HBSS $1 \times$ with $0.1 \%$ gelatin. Residual red blood cells were lysed by hypotonic shock. The number of cells in each band was determined and a differential cell count was performed on cytocentrifuge slides (Cytospin 2; Shandon, Sewickley, PA) after staining with a modified Wright's stain (Stat Stain, VWR Scientific, Piscataway, $\mathrm{NJ}$ ).

Normodense eosinophils obtained from the 1.095-1.100 interface were used in subsequent experiments. The cell population was $87.8 \pm 2.0 \%$ pure $(n=17)$. Viability of the cells after the separation was always more than $98 \%$ as determined by trypan blue exclusion. Contaminating cells were exclusively neutrophils.

Virus preparation. RSV (Long strain) was grown in HEp-2 culture monolayers as described (11). When more than $90 \%$ cytopathic effect was observed $(48-72 \mathrm{~h})$, the virus was harvested. The virus was stored at $-70^{\circ} \mathrm{C}$. $\mathrm{HEp}-2$ cell supernatant was processed in the same way to serve as control. The titer of the virus was $5 \times 10^{5}$ to $5 \times 10^{6}$ plaque-forming units $/ \mathrm{mL}$, as determined by plaque-forming assay.

Immunofluorescence. Eosinophils were incubated with RSV at an m.o.i. of 1 in serum-free HBSS for 2 or $24 \mathrm{~h}$ at $37^{\circ} \mathrm{C}$ with $5 \%$ $\mathrm{CO}_{2}$. After incubation, the cells were washed, fixed on glass slides, and stained with a FITC-conjugated monoclonal antiRSV antibody (Bartels Immunodiagnostic Supplies, Sacramento, $\mathrm{CA})$. The slides were then examined under a fluorescence microscope (Olympus Optical Co. Ltd., Shinjuhn-Tokyo, Japan) by two independent investigators.

Superoxide generation. Generation of superoxide was determined as SOD-inhibitable reduction of ferricytochrome $c$ as previously described (12). The tests were carried out in flatbottom, 96-well microtiter plates (Dynatech Laboratories, Alexandria, VA), and the color change was measured in an automated ELISA reader at $550 \mathrm{~nm}$ (Titertek Multiskan Plus MKII; Flow Laboratories, McLean, VA). After adding the stimuli to the wells, the plate was read six times in the first $30 \mathrm{~min}$ and at 15 -min intervals thereafter until the moment a plateau phase in superoxide production was reached. Between readings, the plate was incubated at $37^{\circ} \mathrm{C}$ with $5 \% \mathrm{CO}_{2}$. The mean of triplicate wells was calculated and SOD control and spontaneous release were subtracted from the test wells. Superoxide generation was expressed as nmol cytochrome $c$ reduction $/ 5 \times 10^{5}$ cells per min as described (12).

Leukotriene production. One million eosinophils were incubated overnight in $1 \mathrm{~mL}$ of RSV-conditioned medium (RPMI 1640 supplemented with $5 \%$ FCS) at an m.o.i. of 2 or in an equal amount of control medium, at $37^{\circ} \mathrm{C}$ and $5 \% \mathrm{CO}_{2}$. After incubation, the cells were washed twice with HBSS and counted, and the viability was determined by trypan blue exclusion. The cells were subsequently incubated in a total volume of $1 \mathrm{~mL}$ with calcium ionophore A23187 at a final concentration of $2.5 \mu \mathrm{M}$ for $10 \mathrm{~min}$ in a shaking water bath. The reaction was stopped by addition of $1.5 \mathrm{~mL}$ of ice-cold methanol. Twenty ng of prostaglandin $\mathrm{B}_{2}$ were added as an internal standard for HPLC analysis. The resultant mixture was centrifuged at $1000 \times g$ for $15 \mathrm{~min}$ at $4^{\circ} \mathrm{C}$. The supernatant was applied to a $\mathrm{C} 18$ reversed phase extraction cartridge (Sep-Pack; Millipore, Waters Associates, Milford, MA) that had been washed previously with $10 \mathrm{~mL}$ of distilled HPLC-grade water and activated with $10 \mathrm{~mL}$ HPLCgrade methanol. After the sample was placed on the cartridge, it was washed with $10 \mathrm{~mL}$ of distilled water and the leukotrienes were eluted with $10 \mathrm{~mL}$ of $70 \%$ methanol. The methanol fraction was evaporated under vacuum in a rotary evaporator (Rotavapor, Buchi, Switzerland) and the residue was redissolved in $500 \mu \mathrm{L}$ of $30 \%$ methanol and stored at $-70^{\circ} \mathrm{C}$ until testing. The samples were injected into a $\mathrm{C} 18$ reverse-phase column (Beckman, San Ramon, CA) and eluted isocratically at a flow rate of $1 \mathrm{~mL} / \mathrm{min}$ in a HPLC system (Pharmacia, Piscataway, NJ) with a solvent system of methanol/water/acetic acid (70/28/2 vol/vol/vol) adjusted to $\mathrm{pH} 5.5$ with ammonium hydroxide. The eluate was monitored at $280 \mathrm{~nm}$ by a wavelength spectrometric detector (Pharmacia). For identification and quantification of $\mathrm{LTC}_{4}$ in the samples, different mixtures of purified $\mathrm{LTC}_{4}$ and prostaglandin $B_{2}$ were prepared in HBSS and processed as described above. Each sample was tested in parallel with these standards.

Reagents. HBSS with and without calcium and magnesium, RPMI 1640, and neonatal calf serum were purchased from Gibco Laboratories (Grand Island, NY). Gelatin was obtained from Bio-Rad Laboratories (Richmond, CA). Dextran, Percoll, PMA, calcium ionophore A23187, formyl-methionyl-leucyl-phenylalanine, SOD, horse-heart ferricytochrome $c$ (type VI), prostaglandin $\mathrm{B}_{2}$, and platelet activation factor $\mathrm{L}-\alpha$-phosphatidylcholine, $\beta$ acetyl- $\gamma$-O-(octadec-9-cis-enyl) (PAF) were purchased from Sigma Chemical Co. (St. Louis, MO). The chemicals were aliquoted and stored at $-20^{\circ} \mathrm{C}$ or $-70^{\circ} \mathrm{C}$ as recommended by the manufacturer. HPLC solvents were obtained from Aldrich Chemical Co. (Milwaukee, WI). Ficoll-Hypaque was obtained from Pharmacia Fine Chemicals (Uppsala, Sweden). Purified $\mathrm{LTC}_{4}$ was a generous gift of Dr. J. Rokach, Merck Frosst, Montreal, Quebec, Canada.

Statistical methods. The $t$ test for paired samples was used to compare group means. All values are expressed as mean \pm SEM.

\section{RESULTS}

Association of RSV with eosinophils. Eosinophils were incubated with live RSV and then stained with FITC-conjugated $\mathrm{MAb}$ to RSV. After $2 \mathrm{~h}$ of incubation, $29.5 \pm 15.8 \%$ of the eosinophils demonstrated significant staining for viral antigen $(n$ $=4)$. The staining appeared as bright spots rather diffusely distributed over the eosinophil cell membrane, sometimes confluent to a larger area of immunofluorescence on the cell (Fig. 1). However, cells incubated with RSV for $24 \mathrm{~h}$ revealed no RSV-specific staining in any of the eosinophil preparations studied $(n=3)$. To exclude the possibility that contaminating neutrophils might show the positive staining, only cell preparations consisting of more than $95 \%$ eosinophils were used for the immunofluorescence studies. Cells incubated with virus-free HEp-2 cell supernatant or control culture medium did not show any fluorescence.

Superoxide production. Eosinophil preparations were stimulated with PMA in a final concentration of 1 or $10 \mathrm{ng} / \mathrm{mL}$ or PAF at a final concentration of $10^{-6} \mathrm{M}$ to establish a reference curve for eosinophil superoxide production kinetics (12). As shown in Figure 2, peak superoxide production was observed after $180 \mathrm{~min}$ of incubation with PMA $1 \mathrm{ng} / \mathrm{mL}$ or PAF $10^{-6}$ M. On the other hand, superoxide production by the eosinophils stimulated with PMA $10 \mathrm{ng} / \mathrm{mL}$ reached a peak level at $30 \mathrm{~min}$. The maximum superoxide production was $38.2 \pm 6 \mathrm{nmol}$ cytochrome $c$ reduction $/ 5 \times 10^{5}$ cells for the high concentration of PMA versus $8.9 \pm 2.7 \mathrm{nmol}$ cytochrome $c$ reduction $/ 5 \times 10^{5}$ 


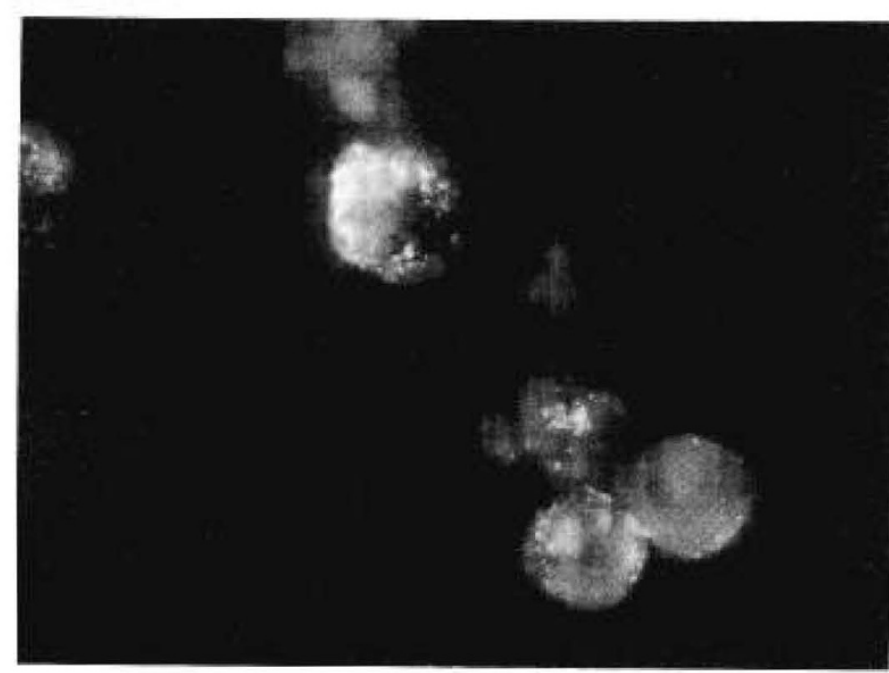
$2 \mathrm{~h}$.

Fig. 1. Immunofluorescence of eosinophils after exposure to RSV for

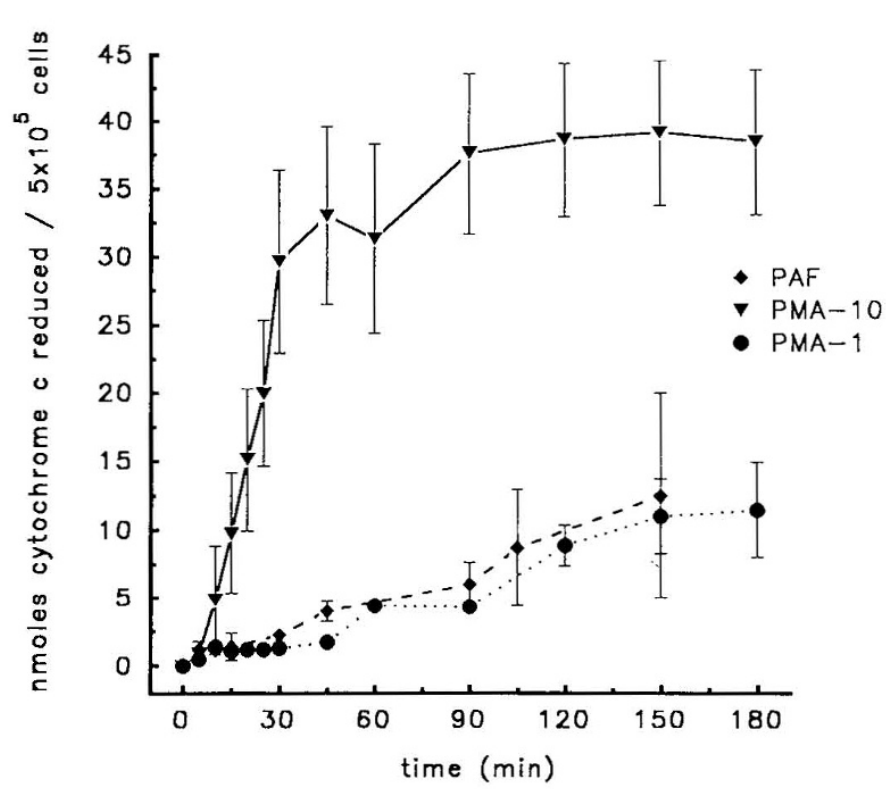

Fig. 2. Kinetics of eosinophil superoxide production after stimulation with PMA $10 \mathrm{ng} / \mathrm{mL}(n=5)$ and $1 \mathrm{ng} / \mathrm{mL}(n=8)$ and PAF $10^{-6} \mathrm{M}(n$ $=3$ ).

cells for the low PMA concentration and $11.5 \pm 7.5 \mathrm{nmol}$ cytochrome $c$ reduction $/ 5 \times 10^{5}$ cells for PAF.

Eosinophils were incubated with live RSV at an m.o.i. of 1, and the kinetics of superoxide release was determined over the following $180 \mathrm{~min}$ (Fig. 3). Eosinophils of three volunteers did not demonstrate any reactivity toward RSV, although the superoxide production by control cells stimulated with PMA was appropriate (data not shown). Eosinophils from two volunteers demonstrated a very low but consistent superoxide release after incubation with the virus (maximal release $1.05 \pm 0.15 \mathrm{nmol}$ cytochrome $c$ reduction $/ 5 \times 10^{5}$ cells). Conversely, cells of three other donors demonstrated a high superoxide production after stimulation with RSV $(9.3 \pm 1.17 \mathrm{nmol}$ cytochrome $c$ reduction/ $5 \times 10^{5}$ cells). Cells of one of these volunteers demonstrated a rather late onset of maximal superoxide production. For the three volunteers whose cells exhibited a high response to RSV, the degree of oxygen radical release was comparable to the amount released by PMA $1 \mathrm{ng} / \mathrm{mL}$ or PAF $10^{-6} \mathrm{M}$. To study the possible confounding effect of superoxide production by contaminating neutrophils in the cell suspensions, purified neutrophils of the same volunteers were incubated with RSV. No

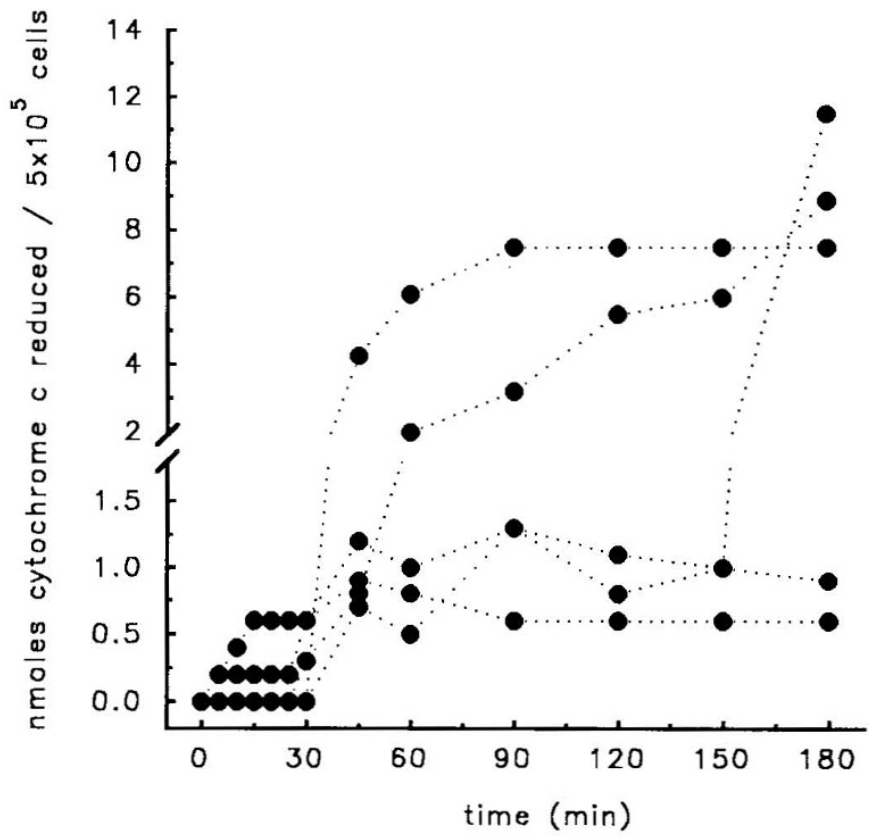

Fig. 3. Kinetics of superoxide production after stimulation with RSV $(n=5)$. Eosinophils from three other donors did not generate superoxide when stimulated with RSV.

RSV-induced superoxide production by the neutrophils could be detected, although the cells were activated appropriately by PMA and formyl-methionyl-leucyl-phenylalanine (data not shown). In addition, different percentages of neutrophils $(5-15 \%)$ in the cell suspensions did not affect the activation of eosinophils (data not shown). The stock RSV preparation did not contain measurable amounts of superoxide.

To evaluate if RSV had a priming effect on eosinophils, resulting in a more pronounced production of superoxide after subsequent challenge, eosinophils were incubated with the virus at an m.o.i. of 1 for $30 \mathrm{~min}$ at $37^{\circ} \mathrm{C}$ and $5 \% \mathrm{CO}_{2}$. After two washing steps with HBSS, the cells were plated and challenged with PMA at a concentration of $1 \mathrm{ng} / \mathrm{mL}$. The data on eosinophil preparations of four different volunteers are presented in Figure 4. The maximal PMA-induced superoxide release by cells preincubated with RSV was 32.6, 16.5, 7.3, and $29 \mathrm{nmol}$ cytochrome $c$ reduction $/ 5 \times 10^{5}$ cells in each of four experiments. These values are 90 to $250 \%$ higher than those in corresponding control experiments on cells incubated in virus-free medium $(9,9.2,3.1$, and $16.4 \mathrm{nmol}$ cytochrome $c$ reduction $/ 5 \times 10^{5}$ cells, respectively). The mean peak of superoxide production after PMA challenge was $21.4 \pm 5.8 \mathrm{nmol}$ cytochrome $c$ reduction $/ 5 \times 10^{5}$ eosinophils incubated in the presence of virus versus $9.4 \pm 2.7$ nmol cytochrome $c$ reduced $/ 5 \times 10^{5}$ cells incubated in control medium $(p<0.04)(n=4)$.

Eosinophils incubated with HEp-2 cell supernatant did not produce detectable superoxide, nor was a priming effect noted.

Leukotriene release. Incubation of $1 \times 10^{6}$ purified eosinophils from different donors for up to $12 \mathrm{~h}$ in the presence of live RSV or HEp-2 cell supernatant did not induce release of any sulfidopeptide leukotrienes. Shorter incubations $(30,60$, or $120 \mathrm{~min})$ did not result in $\mathrm{LTC}_{4}$ release either (data not shown). However, incubation of the eosinophils for $12 \mathrm{~h}$ in control medium followed by a challenge with a suboptimal concentration of calcium ionophore A23187 resulted in the release of detectable amounts of $\mathrm{LTC}_{4}\left(4.2 \pm 1.3 \mathrm{ng} \mathrm{LTC} / 1 \times 10^{6}\right.$ cells $)$. When the eosinophils were preincubated with RSV for $12 \mathrm{~h}$ and then challenged with calcium ionophore, significantly higher amounts of $\mathrm{LTC}_{4}$ were released $\left(9.16 \pm 1.04 \mathrm{ng} \mathrm{LTC} 4 / 1 \times 10^{6}\right.$ cells $)(n=6)(p<0.005)$ (Fig. 5). HEp-2 cell-conditioned medium, however, did not show any priming effect on the eosinophils. 


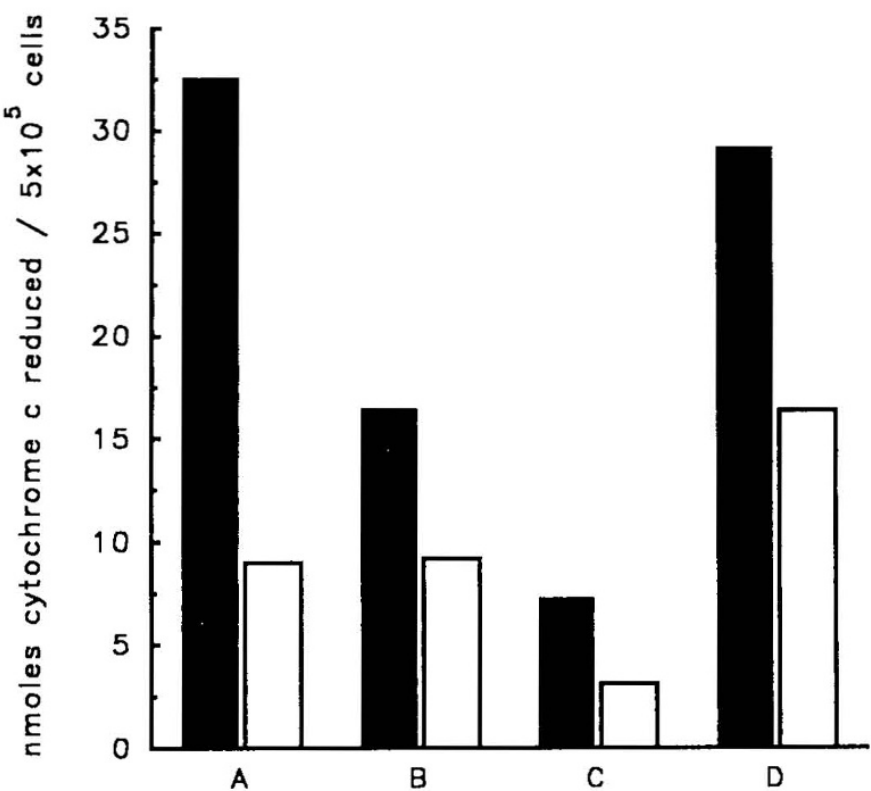

Fig. 4. Maximal superoxide production by PMA $1 \mathrm{ng} / \mathrm{mL}$ for cells preincubated with RSV (filled bars) or control medium (open bars) by eosinophils of four different donors.

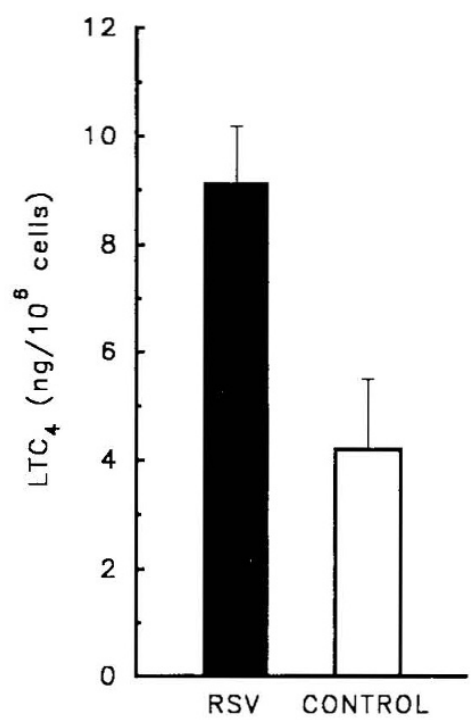

Fig. 5. $\mathrm{LTC}_{4}$ release by eosinophils after challenge with calcium ionophore A23187 at a final concentration of $2.5 \mu \mathrm{M}$. Cells were preincubated with RSV or control medium $(n=6)$.

\section{DISCUSSION}

The findings of this study suggest that RSV is capable of stimulatory interaction with eosinophils. One third of the cells demonstrated specific fluorescent membrane staining after $2 \mathrm{~h}$ of exposure to the virus. This finding contrasts with a previous report in which positive staining was not obtained after incubation of polymorphonuclear granulocytes with RSV and subsequent staining of the cells with anti-RSV MAb (13). However, nonpurified granulocyte suspensions were used in that study, and the cells were only examined after $24 \mathrm{~h}$. In the present study, RSV-eosinophil interactions reversed spontaneously by $24 \mathrm{~h}$ of incubation.

Activation of eosinophils of healthy subjects by respiratory syncytial virus described in the present study was evident from the release of superoxide and $\mathrm{LTC}_{4}$. The magnitude of superoxide production due to RSV stimulation varied among the subjects but was clearly detectable in five of eight individuals $(63 \%)$ tested. Furthermore, the virus primed the cells to release signifi- cantly more superoxide on subsequent challenge with PMA and also sensitized eosinophils to release higher amounts of $\mathrm{LTC}_{4}$ in response to a subsequent challenge with calcium ionophore.

The mechanism and initiating steps of the oxidative metabolism of neutrophils is well understood. A similar understanding of the respiratory burst of eosinophils has been inhibited because of technical difficulties in separating cells from peripheral blood and because superoxide assays have required large numbers of cells. In the present study, a recently described microassay for measurement of superoxide production by small numbers of phagocytic cells was used $(12,14,15)$. PMA stimulates eosinophils to release toxic oxygen metabolites through a mechanism bypassing the initial receptor-mediated activation and starting the chain of superoxide generation directly at the level of phosphokinase C. PAF stimulates the cells through interaction with specific membrane receptors (16). The mechanism by which RSV activates the eosinophils to release oxygen radicals is not clear. Nonspecific phagocytosis of the virus by the cells is possible, but the interaction of RSV with a thus far unidentified putative receptor on the eosinophils cannot be ruled out. The possibility that eosinophils are indirectly activated by factors released by HEp-2 cells infected with RSV cannot be ruled out completely by this study, although to our knowledge there exists no evidence suggesting HEp-2 cells as a source of cytokines or other factors inducing or mediating stimulation of eosinophils.

The interindividual variability in superoxide generation cannot be explained at the present time. The donors had no symptoms of atopic disease and did not report other recent illness, nor were they taking any medication that could blunt or accentuate the response. Serum-specific anti-RSV antibody titers as determined by ELISA were similar for all the subjects (data not shown), probably excluding variability in immune complex formation as a mechanism.

$\mathrm{RSV}$ did not induce directly a release of $\mathrm{LTC}_{4}$ from the eosinophils. However, cells incubated in the presence of the virus exhibited a significantly stronger response when challenged subsequently with calcium ionophore. The priming of eosinophils by monokines and eosinophil chemotactic factors has been previously described $(17,18)$. Ingestion of the viral particles by the cell or interaction of RSV with the eosinophil membrane may render the cells more active upon stimulation with a chemical stimulus such as calcium ionophore.

To date, the only reports describing the activation of granulocytes by RSV in vitro involve the interaction of RSV and neutrophils. Neutrophils produce superoxide and thromboxane $\mathbf{B}_{2}$ when challenged with RSV (19), demonstrate a significant chemiluminescence when incubated with RSV-antibody immune complexes (20), attach to RSV-infected HEp-2 cells (11), and are cytotoxic for RSV-infected targets (21). The present study provides information on RSV-specific activation of purified eosinophils.

The demonstration that RSV can both induce the production of superoxide and prime the eosinophils to release higher amounts of mediators after subsequent challenge leads to the speculation that some of the inflammatory signs seen in the airways of children with RSV bronchiolitis might be eosinophilinduced. Indeed, it has been shown that eosinophil mediators such as major basic protein and products of the respiratory burst can induce damage of respiratory epithelium and airway smooth muscle in vitro (22-26). Viral damage to respiratory epithelium could work in concert with toxic damage by eosinophil products and edema with bronchoconstriction induced by $\mathrm{LTC}_{4}$ to bring about the airway obstruction seen in RSV bronchiolitis.

Acknowledgments. The authors thank Dr. W. Busse, Madison, WI for his highly appreciated help in teaching the purification of eosinophils. We are grateful to the staff of the Laboratory of Hematology, The Children's Hospital, Buffalo, for performing the cell counts. 


\section{REFERENCES}

1. Anderson LJ, Parker PA, Strikas RL 1990 Association between respiratory syncytial virus outbreaks and lower respiratory tract deaths of infants and young children. J Infect Dis 161:640-646

2. Pullan CR, Hey EN 1982 Wheezing, asthma, and pulmonary dysfunction 10 years after infection with respiratory syncytial virus in infancy. $\mathrm{Br}$ Med J 284:1665-1669

3. Venge $\mathrm{P} 1990$ The human eosinophil in inflammation. Agents Actions 29:122126

4. Kim HW, Canchola JG, Brandt CD, Pyles G, Chanock FM, Jensen K, Parrott RH 1969 Respiratory syncytial virus disease in infants despite prior administration of antigenic inactivated vaccine. Am J Epidemiol 89:422-434

5. Chin J, Magoffin RL, Shearer LA, Schieble JH, Lennette EN 1969 Field evaluation of a respiratory syncytial virus vaccine and a trivalent parainfluenza virus vaccine in a pediatric population. Am J Epidemiol 89:449-463

6. Volovitz B, Faden H, Ogra PL 1988 Release of leukotriene $\mathrm{C}_{4}$ in respiratory tract during acute viral infection. J Pediatr 112:218-222

7. Volovitz B, Welliver RC, De Castro G, Krystofik DA, Ogra PL 1988 The release of leukotrienes in the respiratory tract during infection with respiratory syncytial virus: role in obstructive airway disease. Pediatr Res 24:504507

8. Garofalo R, Kimpen JLL, Welliver RC, Ogra PL 1992 Eosinophil degranulation in the respiratory tract during naturally acquired respiratory syncytial virus infection. J Pediatr 120:28-32

9. Welliver RC 1988 Detection, pathogenesis, and therapy of respiratory syncytial virus infections. Clin Microbiol Rev 1:27-39

10. Gärtner I 1980 Separation of human eosinophils in density gradients of polyvinylpyrrolidone-coated silica gel (Percoll). Immunology 40:133-136

11. Faden H, Hong JJ, Ogra FL 1984 Interaction of polymorphonuclear leukocytes and viruses in humans: adherence of polymorphonuclear leukocytes to respiratory syncytial virus-infected cells. J Virol 52:16-23

12. Sedgwick JB, Vrtis RF, Gourley MF, Busse WW 1988 Stimulus-dependent differences in superoxide anion generation by normal human eosinophils and neutrophils. J Allergy Clin Immunol 81:876-883

13. Midulla F, Huang YT, Gilbert IA, Cirino NM, McFadden Jr ER, Panuska JR 1989 Respiratory syncytial virus infection of human cord and adult blood monocytes and alveolar macrophages. Am Rev Respir Dis 140:771-777

14. Pick E, Mizel D 1981 Rapid microassays for the measurement of superoxide and hydrogen peroxide production by macrophages in culture using an automatic enzyme immunoassay reader. J Immunol Methods 46:211-226

15. Mayo LA, Curnutte JT 1990 Kinetic microplate assay for superoxide production by neutrophils and other phagocytic cells. Methods Enzymol 186:567574

16. Kroegel C, Yukawa T, Westwick J, Barnes PJ 1989 Evidence for two platelet activating factor receptors on eosinophils: dissociation between PAF-induced intracellular calcium mobilization, degranulation and superoxide anion generation in eosinophils. Biochem Biophys Res Commun 162:511-521

17. Dessein AJ, Lee TH, Elsas P, Ravalese III J, Silberstein D, David JR, Austen KF, Lewis PA 1986 Enhancement by monokines of leukotriene generation by human eosinophils and neutrophils stimulated with calcium ionophore A23187. J Immunol 136:3829-3838

18. Tamura N, Agrawal DK, Townley RG 1988 Leucotriene $C_{4}$ production from human eosinophil in vitro. Role of eosinophil chemotactic factors on eosinophil activation. J Immunol 141:4291-4297

19. Faden H, Kaul TN, Ogra PL 1983 Activation of oxidative and arachidonic acid metabolism in neutrophils by respiratory syncytial virus antibody complexes: possible role in disease. J Infect Dis 148:110-116

20. Kaul TN, Faden H, Ogra PL 1981 Effect of respiratory syncytial virus and virus-antibody complexes on the oxidative metabolism of human neutrophils. Infect Immun 32:649-654

21. Kaul TN, Faden H, Baker R, Ogra PL 1984 Virus-induced complement activation and neutrophil-mediated cytotoxicity against respiratory syncytial virus (RSV). Clin Exp Immunol 56:501-508

22. Ayars GH, Altman LC, McManus MM, Agosti JM, Baker C, Luchtel DL Loegering DA, Gleich GJ 1989 Injurious effect of the eosinophil peroxidehydrogen peroxide-halide system and major basic protein on human nasal epithelium in vitro. Am Rev Respir Dis 140:125-131

23. Agosti JM, Altman LC, Ayars GH, Loegering DA, Gleich GJ, Klebanoff SJ 1987 The injurious effect of eosinophil peroxidase, hydrogen peroxide, and halides on pneumocytes in vitro. J Allergy Clin Immunol 79:496-504

24. Rowen JL, Hyde DM, McDonald RJ 1990 Eosinophils cause acute edematous injury in isolated perfused rat lungs. Am Rev Respir Dis 142:216-220

25. Aizawa T, Sekizawa K, Aikawa T, Maruyama N, Itabashi S, Tamura G, Sasaki H, Takishima T 1990 Eosinophil supernatant causes hyperresponsiveness of airway smooth muscle in guinea pig trachea. Am Rev Respir Dis 142:133137

26. Klebanoff SJ, Agosti JM, Jorg A, Waltersdorph AM 1989 Comparative toxicity of the horse eosinophil peroxidase- $\mathrm{H}_{2} \mathrm{O}_{2}$-halide system and granule basic proteins. J Immunol 143:239-244 